\title{
ks. Józef Krukowski, Prawo administracyjne w Kościele, Warszawa 2011, ss. 648
}

Publikacja książki autorstwa ks. prof. Józefa Krukowskiego przez Wydawnictwo Uniwersytetu Kardynała Stefana Wyszyńskiego w Warszawie jest wielce znaczącym wydarzeniem na polu rozwoju nauki w dziedzinie prawa administracyjnego w Kościele.

Jej Autor, będąc wybitnym znawcą, powszechnie znanym i uznanym autorytetem w tej dziedzinie prawa tak w Polsce, jak poza jej granicami, prezentuje pogłębioną naukowo - w serii własnych publikacji z zakresu prawa administracyjnego - nową pozycję, która jest owocem szczególnego zainteresowania i doświadczenia mienioną dziedziną prawa. Wskazuje na to fakt, iż w krótkim czasie po promulgacji nowego Kodeksu prawa kanonicznego, bo już w 1985 roku opracował i opublikował pierwszą książkę z zakresu prawa pod tytułem Administracja w Kościele. Zarys kościelnego prawa administracyjnego (Lublin 1985). Obecna publikacja jest owocem analitycznych badań, krytycznych obserwacji i przemyśleń nad weryfikacją obowiązujących norm kościelnego prawa administracyjnego w wymiarze Kościoła powszechnego i Kościołów partykularnych. Jest ona także odpowiedzią na poważne zapotrzebowanie, zwłaszcza ze strony przełożonych kościelnych oraz ich współpracowników z punktu widzenia wykonywania przez nich aktów władzy administracyjnej. Słowem: ukazujące się dzieło wypełnia poważną lukę w literaturze prawniczej z zakresu prawa administracyjnego, zwłaszcza w Polsce. W tym też kontekście wypada przypomnieć jedną z głównych wytycznych pierwszego Synodu Biskupów z roku 1967, zawartą pod nr 7 zatytułowanym De ordinanda procedura ad tuenda iura subiectiva, w której postulowano uporządkowanie dotychczasowej procedury w kwestii ochrony praw podmiotowych. Może zastanawiać fakt, że w procesie porządkowania odnośnych praw w tak ważnej i złożonej problematyce, ustawodawca nie poświęcił im odrębnej księgi, zamieszczając określone normy w różnych (głównie w I, II i V) księgach kodeksu.

Ks. prof. Krukowski poczynił w tej kwestii interesujące obserwacje i uwagi (zob. Wstęp, s. 12-14), odnosząc się do szerokiej sfery norm i dyspozycji prawa powszechnego i partykularnego, przywołując także rozwiązania z dziedziny świeckich systemów prawa administracyjnego. W aluzjach tych, wprawdzie nie wprost, niemniej w sposób czytelny Autor wyraża po- 
stulat bardziej spójnego i systematycznego ujęcia norm prawa administracyjnego kościelnego (być może w odrębnej księdze nowelizowanego w przyszłości prawa kościelnego).

Tymczasem Autor w nowo opublikowanej książce (Wstęp, s. 12) informuje: „Zawartość obecnej publikacji w stosunku do poprzedniej jest znacznie poszerzona, poprawiona i uzupełniona”; i co istotne, jak sam podkreśla: „Uwzględnia także nowy materiał źródłowy i nowsze publikacje" (tamże).

Oddając głos Autorowi, odnotujmy szczególne propozycje i akcenty w rzeczonej publikacji, które wyznaczają kierunek i merytoryczną strukturę publikacji; a są nimi przede wszystkim: integralne ujęcie problematyki współczesnego prawa administracyjnego, zawarte w ramach pięciu części - usystematyzowanych według kryteriów merytorycznych - w następującym porządku:

- $\quad$ „podstawowe pojęcia i zasady prawa administracyjnego w Kościele (część I),

- $\quad$ struktura organizacyjna administracji w Kościele na szczeblu centralnym i lokalnym (część II),

- akty administracyjne jako typowa forma funkcjonowania administracji w Kościele (część III),

- $\quad$ procedura administracyjna w Kościele (część IV),

- $\quad$ sprawiedliwość administracyjna w Kościele” (część V).

Część I publikacji została zatytułowana „Podstawy prawa administracyjnego w Kościele” (s. 17-45), na którą składają się dwa rozdziały. Pierwszy pod tytułem „Pojęcie administracji i prawa administracyjnego" (s. 29-30). W słowie otwierającym dalsze analizy i refleksje Autor nawiązuje do początków idei prawa administracyjnego, poczynając od aluzji do źródeł prawa rzymskiego, poddaje analizie i opisuje treść pojęcia „administracja”, by następnie scharakteryzować pojęcie administracji w aspekcie podmiotowym: w społecznościach państwowych, a następnie w administracji w Kościele. Autor eksponuje tu podobieństwa i różnice $\mathrm{w}$ rozumieniu i interpretacji tych pojęć w obu systemach prawa (s. 21-24). Z kolei rozważa aspekt przedmiotowy administracji, zachowując podobną kolejność analiz: najpierw mówi o administracji w społecznościach państwowych (s. 24-25), następnie w Kościele (s. 25-26). Również w tym przypadku wskazuje na podobieństwa i różnice w obu systemach w sferze realizacyjnej organów administracji, podyktowanych specyficzną strukturą i konkretnym przedmiotem ich działalności

Kolejnym przedmiotem analiz Autora jest pojęcie prawa administracyjnego. Zagadnienie to rozważa według przyjętego wyżej porządku (s. 26-31): analizuje odnośne kwestie w systemach państw współczesnych, a następnie przechodzi do kwestii w systemie prawa kanonicznego. Szczególnie warto odnotować uwagi dotyczące procesu doskonalenia norm 
prawa administracyjnego w systemie prawa kościelnego (s. 28-29). Rozdział pierwszy tej części analiz kończy się interesującymi uwagami odnoszącymi się do rozwoju nauki prawa administracyjnego, zarówno w ustawodawstwie państwowym, jak i kościelnym (s. 29-31).

Rozdział drugi części pierwszej po tytułem „Teologiczne modele ustroju Kościoła podstawą instytucji prawa administracyjnego” został w całości poświęcony pogłębionej refleksji teologicznej nad ustrojem Kościoła, którego natura i charakter leżą u podstaw prawa administracyjnego w Kościele i wyznaczają jego specyficzną formę (s. 32-45). Autor przywołuje tu, obok przesłanek z dawnej tradycji Kościoła, przesłanki najświeższej daty: z doktryny Soboru Watykańskiego II oraz posoborowych enuncjacji Magisterium Kościoła, stanowiących podstawowe źródło i istotny wyznacznik dla norm prawa administracyjnego w nowym Kodeksie prawa kanonicznego.

Część II książki nosi bogaty w treści tytuł „Organizacja administracji w Kościele”. Rozległość tematyczna podyktowana jest różnorodnością oraz wielopoziomowością struktur instytucji administracji kościelnej: po pierwsze, w skali Kościoła powszechnego (rozdział IV, s. 95-129); po drugie, w wymiarze Kościołów partykularnych (rozdz. V, s. 130-244); wreszcie w ponaddiecezjalnych organach władzy administracyjnej w Kościołach partykularnych (rozdz. VI, s. 247-258). Rozdziały te zawierają analizę organów władzy na szczeblu centralnym, czyli podstawowych organów najwyższej i pełnej władzy: Biskupa Rzymskiego i Kolegium Biskupów oraz organów pomocniczych wyposażonych w kompetencje administracyjne, które zostały poprzedzone trzema rozdziałami (s. 48-95). W rozdziałach tych Autor rozwija i objaśnia kolejno: zasadnicze pryncypia podstawowych pojęć i rodzajów władzy w Kościele oraz zasady relacji między poszczególnymi organami władzy. W ramach wymienionych rozdziałów Autor odnosi się także do kwestii jedności i podziału władzy, porównując rozwiązania w państwach demokratycznych, w państwach totalitarnych i w Kościele (s. 70-79), analizuje i wyjaśnia zasadę koncentracji i dekoncentracji władzy w Kościele (s. 79-87); dalej porusza problem centralizacji i decentralizacji władzy w Kościele (s. 88-90); opisuje funkcję zasady koordynacji administracji kościelnej (s. 90-93); zasadę pomocniczości, która zyskała po Soborze Watykańskim II na znaczeniu, zwłaszcza w realizacji władzy administracyjnej w świetle pogłębionej nauki w odniesieniu do podstawowej zasady w Kościele, określanej mianem communio (s. 94-95).

Część III książki została poświęcona „Aktom administracyjnym”, które - jak to podkreślił sam Autor - są „typowym przejawem działalności władzy wykonawczej” (s. 259). W słowie wprowadzającym do pierwszego rozdziału został nakreślony zarys problematyki, znaczony zasadniczo systematyką kodeksu wedle ustalonego przez prawodawcę porządku: akty administracyjne ogólne (decreta generalia) i instrukcje (instructiones) oraz akty administracyjne konkretne (s. 260). W I rozdziale tej części, pod tytułem „Pojęcie i klasyfikacja 
aktów administracyjnych" (s. 260-289), otrzymujemy opis i interpretację genezy poszczególnych aktów administracyjnych, które nie są bez znaczenia, jak zauważa Autor, w sferze zmiany, nawet aktu uchylenia już istniejących stosunków administracyjnoprawnych (s. 285). Interesujące refleksje odnoszą się tu do „poszczególnych aktów administracyjnych” według wersji tychże aktów w kodeksie z 1983 roku; podczas gdy Autor w miejsce terminu „poszczególny”, wprowadza termin „konkretny”, co w rezultacie zabrzmi: „Konkretne akty administracyjne” (rozdz. I, 2, s. 267). W związku z tym szczególne zainteresowanie budzi szereg uwag dotyczących uwydatnienia różnic, jakie występują między aktem administracyjnym a aktem ustawodawczym i sądowym (2.1. - 2.3., s. 268-281). W konsekwencji powyższych wyjaśnień następuje wyliczenie typowych aktów administracyjnych: „klasyfikacja kościelnych aktów administracyjnych konkretnych” z podaniem różnych czynników i okoliczności, mających wpływ na powstanie konkretnego aktu administracyjnego (3 - 3.9., s. 281-289).

Rozdział II tej części, zatytułowany „Szczególne akty administracyjne” (s. 290), zdaje się sugerować coś więcej, niż określenie zawarte w tytule IV pierwszej księgi Kodeksu prawa kanonicznego: „Poszczególne akty administracyjne”, do których prawodawca zalicza przede wszystkim dekrety i poszczególne nakazy (rozdz. II księgi pierwszej KPK pod tym samym tytułem). Profesor Krukowski pozostając wierny wprowadzonemu nieco odmiennego nazewnictwa - wyrażającego się terminem „konkretny”, po krótkim wprowadzeniu do rozdziału II, użyje tego właśnie terminu w odniesieniu do dekretów i nakazów, co zabrzmi: „Konkretne dekrety i nakazy” (rozdz. II, 1, s. 291). Określając zaraz potem pojęcie dekretu i nakazu, Autor cytuje oba kanony z kodeksu (kan. 48 i 49), które mówią o „poszczególnych dekretach i poszczególnych nakazach”. Wyjaśniając treść odnośnych norm kodeksowych, trzeba stwierdzić, iż wprowadzenie przez Autora terminu „konkretny” w miejsce „szczególny” - singularis (kan. 35), da się zrozumieć dopiero po uważnej lekturze w tej sprawie tekstu (część III, rozdz. I, 2), pod tytułem „Konkretne akty administracyjne” (s. 267-268). Autor przechodzi następnie do omówienia owych konkretnych aktów administracyjnych: reskryptów (II, 2 2.10., s. 302-321); przywilejów (3 - 3.4., s. 321-331); dyspens (4.1. - 4.6., s. 331-343).

Rozdział III tej części poświęcony jest zasadom funkcjonowania administracji kościelnej, które wyznaczają - podkreśla Autor - dwie podstawowe zasady: praworządności i dyskrecjonalności (zob. Słowo wstępne, s. 343). Wedle przyjętej przez siebie metody porównawczej, Profesor wyjaśnia i opisuje powyższe zasady na tle stosowania zasady praworządności w społecznościach państwowych: demokratycznych (s. 347-348) oraz w państwach totalitarnego komunizmu (s. 349). W tej też konwencji przebiegają dalsze analizy i rozważania w odniesieniu do zasady dyskrecjonalności w działalności administracji państwowej (s. 356-358), a następnie w administracji w Kościele (s. 358-361). Osobny punkt Autor poświęcił zasadzie dobra wspólnego, które to kryterium, jako fundamentalne, zostało stosownie wyjaśnione 
(s. 362-364). Kolejny, IV rozdział tej części, dotyczy zagadnień wad kościelnych aktów administracyjnych, którym Autor poświęcił odpowiednio znaczące uwagi (s. 365-378).

Część IV zatytułowana „Procedura administracyjna w Kościele” (s. 379) prezentuje rozbudowany wykład z pogłębioną analizą norm procedury aktów administracyjnych. Istotnym novum w ramach poruszanych kwestii - co zresztą sam Autor podkreśla - jest wprowadzenie przez ustawodawcę norm „procedury administracyjnej ogólnej” (kan. 35-47 KPK), czemu Autor dał szczególny wyraz w rozdz. I tej części, pod tym samym tytułem (s. 382).

Wydaje się, że w tym momencie Autor mógł stanąć przed kwestią: kontynuować, swoje uwagi wedle przyjętego porządku (zob. część II: rozdz. III, IV, V, VI, s. 69-256), wyznaczając ścisły związek z istotnym celem administracji w Kościele, pod tytułem „Sprawiedliwość administracyjna w Kościele” (część V, s. 483-596), czy raczej (co jest przedmiotem szczegółowych analiz w części IV, s. 379-480) podjąć zagadnienia pod tytułem „Procedura administracyjna w Kościele”. Idąc po tej linii rozważań, po uwagach dotyczących procedury administracyjnej ogólnej (s. 382-408), Autor podjął analizę i opis poszczególnych procedur, takich jak: przenoszenie i usuwanie proboszczów (s. 409-424); procedury administracyjne w sprawach małżeńskich (s. 425-445); wymierzanie kar w trybie administracyjnym (s. 447-458); procedura przenoszenia duchownych do stanu świeckiego (s. 459-465); procedury w sprawach dotyczących wyłączenia członków z instytutów życia konsekrowanego, instytutów świeckich i stowarzyszeń życia apostolskiego (s. 467-480). Tak więc problematyka tak zwanej „sprawiedliwości administracyjnej” w Kościele została pomieszczona w ostatniej części dzieła (rozdz. V, s. 483596). Po wyjaśnieniu i uzasadnieniu potrzeby rozwinięcia zagadnień związanych ze stosowaniem zasad sprawiedliwości administracyjnej, naświetlając kwestie w perspektywie historycznej ze szczególnym akcentem na przesłanki Soboru Watykańskiego II (s. 484-511), Autor przywołuje i omawia instytucje i środki administracyjne, dzięki którym w sposób ewidentny realizuje się postulat sprawiedliwości administracyjnej (rozdz. II, s. 511-521). Następnie wiele miejsca poświęca klasycznym instytucjom i środkom, służącym realizacji sprawiedliwości administracyjnej, takim jak rekurs hierarchiczny (rozdz. III, s. 521-540), w tym rekurs do trybunału administracyjnego niższego od Sygnatury Apostolskiej (rozdz. IV, s. 537-542) oraz rekurs do drugiej sekcji Sygnatury Apostolskiej (rozdz. V, s. 542-579). Porusza wreszcie niemniej ważny element w ramach mienionej sprawiedliwości administracyjnej, mianowicie odpowiedzialności organów administracji za szkody wynikłe z nielegalnego aktu administracyjnego (rozdz. VI, s. 580-596).

Podsumowując, należy stwierdzić, iż książka prof. Józefa Krukowskiego jest ważnym i oryginalnym wydarzeniem w literaturze prawniczej w Polsce, ale także dla zagranicy. Publikacja ta jest pierwszym tak szeroko, gruntownie i wyczerpująco opartym na podstawowych źródłach prawa dziełem, które w sposób całościowy ukazuje system prawa administracyjnego 
w Kościele, przy uwzględnieniu najnowszych rozwiązań, propozycji oraz tendencji w tej dziedzinie nauki prawa. Cenne i zasługujące na uwagę jest także to, iż Autor, analizując i omawiając istotne kwestie poszczególnych zagadnień, przywołuje rozwiązania systemów prawa administracyjnego świeckiego, co pozwala dostrzec i wyróżnić specyfikę prawa administracyjnego kościelnego, zgodnie jego tradycją i doświadczeniem, na tle systemów prawa administracyjnego świeckiego.

Publikacja ta, ze względu na jej wielostronne walory naukowe i praktyczne, zasługuje ze wszech miar na uwagę i zainteresowanie nie tylko teoretyków prawa, przełożonych kościelnych, lecz także tych wszystkich, którzy na co dzień zaangażowani są w sferę działalności na polu administracji.

ks. Józef Krzywda CM 